\title{
Students' Perceptions of Entrepreneurship Education in Selected Federal Polytechnics in Nigeria
}

\author{
Odunola Adefunke Adebayo \\ Department of Library and Information Science, School of Communication and Information \\ Technology, Federal Polytechnic, P.M.B. 420, Offa, Kwara State, Nigeria \\ * E-mail of the corresponding author: odun4christ@yahoo.com
}

\begin{abstract}
Entrepreneurship education is introduced in the polytechnics to provide students with basic skills and knowledge to be self-reliant after graduation. This study investigates the perception of polytechnic students towards entrepreneurship education. A descriptive study was conducted in three purposively selected Federal Polytechnics in Nigeria A structured questionnaire that employed 4-likert scale was the instrument used for data collection. A total number of 475 copies of questionnaire were administered to students who were randomly selected for the study. Frequency, percentages and mean aided by Statistical Package for the Social Sciences (SPSS) were used for the analysis. This study reveals that significant number of students positively perceived entrepreneurship education in polytechnics. It was however recommended that the stakeholders should give more support towards the realization of the objectives of the programme.
\end{abstract}

Keywords: Entrepreneurship education, polytechnic students, perception.

DOI: $10.7176 / \mathrm{JEP} / 12-10-15$

Publication date: April $30^{\text {th }} 2021$

\section{Introduction}

Entrepreneurship education was introduced as a compulsory module for tertiary institutions including polytechnics in Nigeria, with the aim of curbing the menace of youth unemployment in the society. The increase in the number of unemployed in Nigeria is alarming and gradually becoming unbearable. Thousands of graduates are produced by Nigerian tertiary institutions on yearly basis, but only a few numbers of them are absorbed into the labour market. Graduate employment also becomes more difficult due to competition for the limited placements available in the job market.

In the recent times, considerable efforts are being made to ameliorate unemployment to the barest minimum. The Federal Government of Nigeria through the National Board Technical Education was able to introduce Entrepreneurship Education to all Nigerian Polytechnics. The efforts of the Federal Government in introducing entrepreneurship programmes is to equip students with entrepreneurial skills, attitude, and competencies that will help them to become job providers and not job seekers which in turn could bring growth and development to the nation's economy. It is to ensure that the enterprising behavior of students is also strengthened (Lome and Yussouf, 2013; Ajulo, 2019).

Entrepreneurship education is aimed at providing learning that will bring improvement to the nation's economy, inculcate entrepreneurship skills in the students, help them to be innovative and also, reduce poverty level. Entrepreneurship education is to shapen students' perception towards the desire for business creation and through entrepreneurship education, the institutions are to inculcate entrepreneurial mind set in the students. Therefore, it is important to have the understanding of the students' perception of entrepreneurship education so as to come up with entrepreneurship programmes that would focus the students. The students' perception would go along way in impacting their attendance and commitment to entrepreneurship education courses. The way the students perceive entrepreneurship education would also affect their entrepreneurial intention (Amanamah, 2017). However, despite the relevance of this programme and the efforts being made in the country, to ensure effective delivery of entrepreneurship education, the rate of unemployment and joblessness is still on the rapid increase. These graduates seem not to have gained the needed skills and knowledge to launch into successful venture. They either rely on government for employment or seek employment with private business sector. Consequently, a large number of graduates from tertiary institutions roam about the streets seeking for white collar jobs which are not readily available despite their exposure to entrepreneurship education (Ajufo, 2019.)

Entrepreneurship education seemed to have been wrongly perceived by some students in tertiary institutions. These graduates seem not to have gained the needed skills and knowledge to launch into successful venture and the concept seems to have been misunderstood by the students. Hence, they either rely on government for employment or seek employment with private business sector. The ability to actualize the objectives of entrepreneurship education depends largely on the perception of the students towards the 
programme. It is on this note, that this paper aimed at studying the perception of polytechnic students towards entrepreneurship education in Nigeria with focus on three Federal Polytechnics.

\subsection{Objectives of the Study}

The objectives of the study are to:

1. ascertain the polytechnic students' perception of entrepreneurship education in Nigeria.

2. investigate the polytechnic students' perception of trainers of entrepreneurship education in their institutions.

3. know the polytechnic students' views on entrepreneurship curriculum and course content.

\subsection{Research Questions}

The study sought answers to the following research questions:

1. What is the polytechnic students' perception of entrepreneurship education in polytechnics, Nigeria?

2. What is the polytechnic students' perception of trainers of entrepreneurship education trainers in polytechnics?

3. What are the views of polytechnic students on entrepreneurship curriculum and course contents?

\section{Literature Review}

Entrepreneurship has been recognized as a significant component in the development of a nations' economy. Abebe (2015) described entrepreneurship as a major catalyst that drives the economy of most nations. It is a major factor that influences the nations' economy in various ways. Alakbarov (2013) opined that nations that embraced entrepreneurship have made progress in addressing the problem of unemployment thereby, achieving impressive results. Entrepreneurship education is a planned process that enables an individual to acquire entrepreneurial skills. Ogundola (2016) described entrepreneurship education as a lifelong learning process, which commences as early as elementary school and continues through all levels of education. It is therefore regarded as the type of education used to deliver entrepreneurial knowledge, skills and abilities to the students, in order to assist them to succeed in their future career as an entrepreneur.

According to Jimah and Unuigbokhai (2011) entrepreneurship education seeks to prepare people especially the youth to be responsible, enterprising individuals who become entrepreneurs and who make contributions to economic development and sustainable communities. Therefore, entrepreneurship education can be identified as a type of education that allows students or learners to show case his skills or talents to the public thereby, making the recipient of the education to become self-employed, competent and having the right perception about entrepreneur. Edokpolor and Somorin (2017), views entrepreneurship education as what equips its recipients with skill to creating something new and means to discovering business opportunities. It also provides practical opportunities for the students to develop entrepreneurial skills which can assist them to successfully launch a new venture.

Perception is an attribute which shapes individual's world view and attitudes. The way students in tertiary institutions perceives entrepreneurship education has a bearing on their commitment to the programme and willingness to run a business. The study by Udo-Imeh, Magaji, Hamidu and Yakubu (2016) on perception of engineering students in Modibbo Adama University of Technology on the need for entrepreneurship education, the relevance of course contents and teachers' competence revealed a positive perception of the students towards the three areas. The students viewed the course as what could get them prepared for future entrepreneurial careers. Entrepreneurship education is perceived as a good policy among the students who were optimistic that the program would reduce unemployment in the country.

Pulka, Rikwentishe and Ibrahim (2014) in their study viewed entrepreneurship education as a progressive development of relevant entrepreneurial skills and habits which enable students to contribute meaningfully towards the growth and development of Nigerian economy. They found out in their study that students hold strong positive attitude towards entrepreneurship education which enables creation of wealth and growth of economy in the society.

Notably, students in different institutions and regions expressed varied perceptions towards entrepreneurship and entrepreneurship education. This is revealed through the study by Lawan, Envuladu, Mohammad,Wali and Mahmoud (2015) where a mixed result showing both negative and positive perceptions expressed by the university students used for the study. Those with negative perception pointed out that the course was not adequate and too generic. The study further revealed an important concern expressed by the students which could have affected their perception of the programme. The student viewed the training content as more of theories than practical and the course content should be improved. The way students perceive entrepreneurship education is significant to their desires to becoming entrepreneurs. Ogundola (2016) opined that a person would likely engage in entrepreneurial act when he has a positive perception towards entrepreneurship. The curriculum content of entrepreneurship education is to be designed in such a way that the students would be motivated to critically think towards creative and profitable business ideas. 


\section{Methodology}

The study adopted a descriptive survey and the population of the study is made up of the graduating classes of National Diploma and Higher National Diploma (HND) in the selected polytechnics which are Federal Polytechnic Ede; Federal Polytechnic, Ado-Ekiti and Federal Polytechnic, Offa. Accidental sampling technique was adopted to select four hundred and seventy-five (475) respondents as sample for the study. Out of the four hundred and seventy-five copies of questionnaire that were distributed, four hundred and fifty (450) were properly filled and returned This makes a return rate of $94.7 \%$. ND I students were exempted from the study because the researcher believed they were yet to have in-depth information on entrepreneurship education.

Questionnaire titled Students Perception of Entrepreneurship Education (SPEE) was used for data collection in this study. Frequency, percentages and mean were used for analysis.

\section{Data Analysis and Results Interpretation}

The mean score of the items on the questionnaire were computed to determine the perception status of the respondents. A mean score of 2.50 and above $(x \geq 2.50)$ implies positive response to the items while a mean score that is below $2.50(\mathrm{x}<2.50)$ implies negative response as shown on table 2,3 and 4 .

Table 1: Educational level of respondent

\begin{tabular}{lcc}
\hline & Frequency & Percent \\
\hline Class of Respondents & & \\
HND II & 283 & 62.89 \\
ND II & 167 & 37.11 \\
Total & 450 & 100.00 \\
Gender of Respondents & & \\
$\quad$ Male & 236 & 52.44 \\
$\quad$ Female & 214 & 47.56 \\
$\quad$ Total & 450 & 100.00 \\
Age of Respondents & & \\
31 and above & 10 & 2.22 \\
$26-30 \quad$ & 86 & 19.11 \\
$21-25$ & 251 & 55.78 \\
$16-20$ & 103 & 22.89 \\
Total & 450 & 100.00 \\
\hline
\end{tabular}

Table 1 shows the demographic data of the respondents. The Table reveals the class of respondents where $283(62.89 \%)$ are HND II students, and $167(37.11 \%)$ ND II students. The result revealed that the majority of the respondents were in HND II. The table also reveals that $236(52.44 \%)$ were male while214 $(47.56 \%)$ were female the result shows that the male outnumbered the female respondents. The age of the respondents shows that the highest number of the respondents $251(55.78 \%)$ fall within the age group of 21-25 while the lowest percentage $10(2.22 \%)$ falls within 31 and above. This implies that majority of the respondents are less than thirty years of age and they are youths.

Table 2: Mean Score of Perception of Polytechnic Students towards Entrepreneurship Education

\begin{tabular}{lcccccc}
\hline STATEMENTS & $\begin{array}{l}\text { Strongly } \\
\text { disagree }\end{array}$ & Disagree & Agree & $\begin{array}{l}\text { Strongly } \\
\text { agree }\end{array}$ & Mean & Rank \\
\hline $\begin{array}{l}\text { Entrepreneurship education is a good initiative } \\
\text { and should be encouraged }\end{array}$ & 29 & 19 & 90 & 312 & 3.52 & 1 \\
$\begin{array}{l}\text { Entrepreneurship education would reduce } \\
\text { unemployment among youths }\end{array}$ & 37 & 26 & 129 & 258 & 3.35 & 4 \\
$\begin{array}{l}\text { Entrepreneurship education could help to raise } \\
\text { standard of living }\end{array}$ & 25 & 31 & 156 & 238 & 3.35 & 4 \\
$\begin{array}{l}\text { Entrepreneurship education could help to } \\
\text { boost Nigeria economy }\end{array}$ & 26 & 26 & 152 & 246 & 3.37 & 2 \\
$\begin{array}{l}\text { Entrepreneurship education would enhance } \\
\text { the ability to identify business opportunities }\end{array}$ & 20 & 34 & 161 & 235 & 3.36 & 3 \\
$\begin{array}{l}\text { Entrepreneurship education would enhance } \\
\text { the skill to develop business plans }\end{array}$ & 25 & 27 & 157 & 241 & 3.36 & 3 \\
\hline
\end{tabular}


Table 2 shows the mean score of perception of polytechnic students towards entrepreneurship education. A mean score of below 2.50 shows that respondents disagreed with the identified perception, a mean score of 2.50 and above means that respondents agreed and 3.00 and above means respondents strongly agreed with the perception. The Table shows that respondents strongly agreed with the item which states that "Entrepreneurship education is a good initiative and should be encouraged" and it has a mean score of 3.52, followed by "Entrepreneurship education could help to boost Nigeria economy" with a mean score of 3.37. None of the perception has a mean value of below 3 which implies that all the respondents strongly agreed with the items on perceptions of Polytechnic Students towards Entrepreneurship Education.

Table 3 shows the views of polytechnic students on entrepreneurship curriculum and course contents. The mean score of "Entrepreneurship courses provide students better understanding about business" is the highest (3.35) which implies that it is the major view of polytechnic students on entrepreneurship curriculum and course contents that respondents strongly agree and hold. "Entrepreneurship education enables students to develop entrepreneurship knowledge and skills" is another major view with mean score of 3.30 and "Entrepreneurship education covers how business opportunities can be identified" with a mean score of 3.27. Respondents strongly agree with all the identified views as all the mean scores are greater than 3.00 .

Table 3: Mean Score of Views of Polytechnic Students on Entrepreneurship Education Curriculum and Course Contents

\begin{tabular}{|c|c|c|c|c|c|c|}
\hline Factors & $\begin{array}{l}\text { Strongly } \\
\text { disagree }\end{array}$ & Disagree & Agree & $\begin{array}{l}\text { Strongly } \\
\text { agree }\end{array}$ & Mean & Rank \\
\hline $\begin{array}{l}\text { Entrepreneurship courses provide students } \\
\text { better understanding about business }\end{array}$ & 23 & 24 & 177 & 226 & 3.35 & 1 \\
\hline $\begin{array}{l}\text { Entrepreneurship education enables students to } \\
\text { develop entrepreneurship knowledge and skills }\end{array}$ & 25 & 31 & 176 & 218 & 3.30 & 2 \\
\hline $\begin{array}{l}\text { Entrepreneurship education curriculum is rich } \\
\text { and comprehensive }\end{array}$ & 12 & 52 & 229 & 157 & 3.18 & 5 \\
\hline $\begin{array}{l}\text { Entrepreneurship education covers how } \\
\text { business opportunities can be identified }\end{array}$ & 22 & 35 & 194 & 199 & 3.27 & 3 \\
\hline $\begin{array}{l}\text { The course outline provides students with } \\
\text { feasibility studies }\end{array}$ & 16 & 55 & 233 & 146 & 3.13 & 6 \\
\hline $\begin{array}{l}\text { The course covers basic skills required for } \\
\text { entrepreneurship }\end{array}$ & 16 & 48 & 204 & 182 & 3.23 & 4 \\
\hline
\end{tabular}

Table 4 shows the Polytechnic students' perceptions of entrepreneurship education's trainers or lecturers. The mean score of "The lecturers encourage students to participate in entrepreneurship activities" is the highest (3.25) which implies that it is the polytechnic students' perceptions of entrepreneurship education's trainers or lecturers that respondents strongly agree. "The lecturers are experienced and competent course presenters" is another major perception and with mean score of 3.21 and "The lecturers are experienced and competent course presenters" with a mean score of 3.18. Respondents strongly agree with all the identified polytechnic students' perceptions of entrepreneurship education's trainers or lecturers as all the mean scores are greater than 3.00 .

Table 4: Mean Score of Polytechnic students' perceptions of entrepreneurship education's trainers or lecturers

\begin{tabular}{lcccccc}
\hline Factors & $\begin{array}{l}\text { Strongly } \\
\text { disagree }\end{array}$ & Disagree & Agree & $\begin{array}{l}\text { Strongly } \\
\text { agree }\end{array}$ & Mean & Rank \\
\hline $\begin{array}{l}\text { The lecturers are experienced and competent } \\
\text { course presenters }\end{array}$ & 20 & 53 & 203 & 174 & 3.18 & 3 \\
$\begin{array}{l}\text { The lecture stimulates the students' interest } \\
\text { in entrepreneurship }\end{array}$ & 17 & 58 & 222 & 153 & 3.14 & 4 \\
$\begin{array}{l}\text { Students are encouraged to consider starting } \\
\text { their own business }\end{array}$ & 22 & 45 & 198 & 185 & 3.21 & 2 \\
$\begin{array}{l}\text { The lecturers encourage students to } \\
\text { participate in entrepreneurship activities } \\
\text { The lecturers show much interest in teaching } \\
\text { the course }\end{array}$ & 18 & 44 & 196 & 192 & 3.25 & 1 \\
\hline
\end{tabular}




\section{Discussion of Findings}

The result revealed that the respondents have a positive perception towards entrepreneurship education. They strongly agree with all the identified perceptions. The students agreed that entrepreneurship education is a good initiative and should be encouraged. They also agreed that it would reduce unemployment among youth and would also enhance ability to identify business opportunities. These findings agree with the study of Dutse, Mamaki and Djibo (2013) where majority of the polytechnic students positively perceive entrepreneurship education. The polytechnic students are found to show more interest and commitment to entrepreneurship education. This could be as a result of their exposure to many vocational and technical trainings (Lawan et al, 2015). On the views of polytechnic students on curriculum and course contents, the study revealed that the respondents agreed with all the items signifying that entrepreneurship education provide students with better understanding of business, enables student to develop entrepreneurship knowledge and skills. In their study UdoImeh et al. (2016) found that students positively perceived the relevance of the curriculum and course contents. Adediran and Onifade (2013) also revealed that the curriculum course contents are critical to the successful implementation of entrepreneurship education at all levels. The respondents strongly agreed on all items on perception of entrepreneurship education's trainers or lecturers. The major perception with the highest mean score (3.25) is that "the lecturers encourage students to participate in entrepreneurship activities".

\section{Conclusion}

Based on the findings of this research work, the study concludes that the polytechnic students positively perceived entrepreneurship education. They perceived it to be a good initiative which could solve the problem of unemployment among the graduates and would help to boost Nigerian economy. The Federal Polytechnic students had positive perception of the course contents and lecturers' competence. All these are strategically important to the achievement of the outcomes of entrepreneurship education in polytechnics.

\section{Recommendations}

1) Entrepreneurship education is widely acceptable by polytechnic students. Therefore, more support should be provided by stakeholders to encourage entrepreneurship practice after graduation.

2) The curriculum and course contents should be provided with more detailed and comprehensive information, to enable the students have idea of feasibility studies.

3) The trainers or lecturers should be motivated to show more interest in teaching the course.

4) More entrepreneurship activities should be organized in Nigeria polytechnics to influence their involvement in business activities.

\section{Acknowledgment}

This Research was funded by the TETFund Research Fund.

\section{References}

Abebe, A. (2015). Attitudes of undergraduate students towards self-employed in Ethiopian public universities. International Journal of Business and Management Review 3(7), 1-10.

Adediran, A.A. and Onifade, C.A. (2013). The perception of students on the need for entrepreneurship education in teacher education programme. Global Journal of Human Social Sciences 13(3), 21-79.

Ajufo, B. I. (2019). An evaluation of students' attitude towards entrepreneurship education in some Nigerian tertiary institutions. The Journal of Positive Psychology and Counseling 3 (2), 62-72

Alekbarov, Z. (2010). Azerbaijan's success story on Sustainable Entrepreneurship Development through Adoption of Policies, Financing and Innovative Strategies, in International Conference on Policies to Address Financing and Entrepreneurial Challenges in High-growth Innovative Firms, Helsinki.

Amanamah, R. B. (2017). Tertiary students' attitude towards entrepreneurship education in Ghana. Journal of Small business and Entrepreneurship Development 5(2) 125-133.

Dutse,U Y. Mamaki U.P. and Djibo, I. (2013). Perception and Attitude of Students of Tertiary Institutions towards Entrepreneurship Education in Nigeria. IOSR Journal of Humanities and Social Science 15(3) 5-8 
Edokpolor, J. E. and Somorin, K. (2017). Entrepreneurship education programme and its influence in developing entrepreneurship key competencies among undergraduate students. Problems of Education in the $21^{\text {st }}$ century. $75(2), 144-156$.

Jimah, M.S. \& Unigbokhai, O.A. (2011). Entrepreneurship Education: a tool for sustainable developmentNigeriaFde:IIC:/user/user/Desktoplentrinure\%20folder/Entrtepreneurship\%20Education\% $20 \%$ 20M.S.J\%20LIBRARIES.htm.

Lame, S.M. and Yussof, W.F.W (2013). The perception of students towards entrepreneurship courses: An Empirical Study of Nigerian Polytechnics Students. A paper delivered at the 2nd International Conference on Technology Management Business and Entrepreneurship at Mahkota Hotel Melako, Malaysia, 5th December, 2013

Ogundola, P.I. (2016). Relevance of Entrepreneurial Studies as perceived by Vocational Education Undergraduate Students in Nigeria. British Journal of Education 4(12) 13-24.

Puka, B.M; Rikwentishe, R.; and Ibrahim, B. (2014). An Evaluation of Students Attitude towards Entrepreneurship Education in some selected Universities in North East, Nigeria. Global Journal of Management and Business Research: Administration and Management 14(8) 1-7.

Udo-Imeh, P. Magaji, B.; Hamidu, A. and Yakubu, K. (2016). Perceptions of Entrepreneurship Education by Engineering Students of Modibbe Adaima University of Technology. Yola, Nigeria. African Journal of Business management, 10(4) 352-360. 